\title{
STUDI HASIL PEMERIKSAAN UREUM DAN ASAM URAT PADA PENDERITA TUBERKULOSIS PARU YANG MENGONSUMSI OBAT ANTI TUBERKULOSIS(OAT) FASE INTENSIF
}

\author{
Syahida Djasang ${ }^{1}$, Meli Saturiski ${ }^{2}$ \\ 1,2 Jurusan Analis Kesehatan Poltekkes Makassar \\ Koresponden :syahida.djasang@gmail.com
}

\begin{abstract}
ABSTRAK
Kasus Tb Paru di Indonesia menduduki peringkat ke dua, lebih dari 95\% kematian akibat infeksi yang disebabkanMycobacterium Tuberculosis. Salah satu upaya Kemenkes RI ialah Program pengobatan Nasional untuk pemberantasan Tb Paru dengan pengobatan Obat Anti Tuberkulosis. OAT merupakan pengobatan jangka panjang, penggunaannya dapat mempengaruhi fungsi ginjal, yang dapat mengakibatkan adanya penurunan fungsi ekskresi ginjal. Hal ini dapat menyebabkan meningkatnya kadar ureum dan asam urat. Akibat efek samping dari pengobatan OAT KDT pada fase intensif yang menjadi salah satu pemicu ialah kombinasi ZE, dimana menfasilitasi pertukaran ion di tubulus ginjal yang menyebabkan reabsorpsi berlebihan asam urat. Tujuan penelitian ini untuk mengetahui gambaran hasil pemeriksaan ureum dan asam urat pada penderita tuberkulosis paru yang mengonsumsi Obat Anti Tuberkulosis fase intensif. Penelitian ini bersifat deskriptif. Dari 30 sampel penderita tuberkulosis paru yang diambil secara purposive sampling dari tanggal 15 februari s/d 9 mei 2018 di Puskesmas Jumpandang Baru dan Puskesmas Barabaraya diperoleh hasil pemeriksaan ureum yang meningkat $5(16.67 \%)$ sampel dan $25(83,33 \%)$ sampel menunjukan kadar ureum normal dan hasil pemeriksaan asam urat yang mengalami peningkatan sebanyak $18(60,0 \%)$ sampel dan 12 (40,0\%) sampel menunjukkan kadar ureum normal. Disarankan pada penderita $\mathrm{Tb}$ paru untuk melakukan pemeriksaan laboratorium untuk parameter pemeriksaan yang lain.
\end{abstract}

Kata Kunci : Tb Paru, OAT, Ureum, Asam Urat

\section{Latar Belakang}

Penyakit TuberkulosisParu (Tb Paru) merupakan suatu penyakit infeksi yang disebabkan bakteri berbentuk batang (basil) yang dikenal dengan nama Mycobacterium tuberculosis. Penularan penyakit ini melalui perantaraan ludah, dahak atau droplet penderita yang mengandung bakteri yang dapat masuk ke dalam tubuh manusia melalui saluran pernafasan. Pada saat batuk atau bersin, pasien menyebarkan kuman ke udara dalam bentuk percikan dahak (droplet nuclei). Sekali batuk dapat menghasilkan sekitar 3000 percikan dahak dan akan mudah terinfeksi oleh orang lain yang memiliki imunitas tubuh menurun. (Sholeh S. Naga, 2013).

Tb Paru adalah salah satu dari 10 penyebab kematian terbanyak di dunia. Lebih dari 95\% kematian akibat tuberkulosis terjadi di negara 
berpenghasilan rendah dan menengah. Tujuh negara menyumbang terbesar adalah India, diikuti oleh Indonesia, China, Filipina, Pakistan, Nigeria, dan Afrika Selatan.

Kasus $\mathrm{Tb}$ Paru di Indonesia menduduki nomor dua terbanyak setelah India, sehingga harus ada upaya sungguh-sungguh dari seluruh pihak terkait untuk menurunkannya.

Setelah dinyatakan positif pasien $\mathrm{Tb}$ Paru, pasien harus melakukan pengobatan Obat Anti Tuberkulosis (OAT). Bagi banyak pasien, masa pengobatan menjadi berat karena efek obat yang menyiksa dan lamanya waktu pengobatan. Meski demikian pasien tidak boleh meninggalkan pengobatan karena kuman TbParu bisa menjadi kebal. (Carolus, 2017)

Program

Nasional

pemberantasan $\mathrm{Tb}$ Paru di Indonesia sudah dilaksanakan sejak tahun 1950an sampai saat ini. Sebagian besar pasien Tb Paru dapat menyelesaikan pengobatan tanpa mengalami efek samping OAT yang berarti. Namun, beberapa pasien dapat saja mengalami efek samping yang merugikan atau berat. Guna mengetahui terjadinya efek samping OAT, sangat penting untuk memantau kondisi klinis pasien selama masa pengobatan sehingga efek samping berat dapat segera diketahui dan ditatalaksana secara tepat.

Pengobatan OAT terdiri dari fase intensif yaitu pengobatan OAT 4 kombinasi Dosis Tetap (KDT) selama 2 bulan dikomsumsi setiap hari dengan pengawasan, yang terdiri dari Paket OAT yaitu Rifampisin (R), Isoniazid $(\mathrm{H})$, Pirazinamid $(\mathrm{Z})$. Sedangkan sampai fase lanjutan cukup lama pengobatan di atas 6 bulan. Obat dapat menjadi zat toksik dalam tubuh, akibat lamanya mengonsumsi obat akan berpengaruh terhadap organ tubuh lainnya misalnya organ ginjal, bahkan bisa berdampak pada penyakit gagal ginjal, dimana organ tersebut berfungsi sebagai alat pembuangan atau ekskresi. Obat-obatan dieliminasi dari dalam tubuh baik dalam bentuk yang tidak diubah oleh proses ekskresi maupun diubah menjadi metabolit. Ginjal merupakan organ yang paling penting untuk mengeluarkan obat-obatan dan hasil metabolitnya.

Pirazinamid dan Ethambutol merupakan kombinasi $\mathrm{ZE}$ yang bersifat tuberkulostatik. Dimana obat pirazinamid memiliki metabolit (asam pirazinoat), dan Ethambutol memiliki $10 \%$ sisa metabolisme diantaranya asam karboksilat dan dapat menyebabkan hiperurisemia. Jumlah asam dalam tubuh dapat meningkat jika mengkonsumsi suatu asam atau suatu bahan yang diubah menjadi asam, dan dapat mengurangi ekskresi asam urat melalui ginjal.

Kejadian gangguan fungsi ginjal lebih tinggi pada kombinasi dibanding dengan pemberian Pirazinamid atau Ethambutol saja, Pirazinamid dan Ethambutol ini yang menfasilitasi pertukaran ion di tubulus ginjal yang menyebabkan reabsorpsi berlebihan asam urat karena Jumlah asam dalam tubuh dapat meningkat jika mengonsumsi suatu asam atau suatu bahan yang diubah menjadi asam. sehingga menimbulkan hiperurisemia dan jika kedua obat digunakan bersamaan efek yang ditimbulkan lebih besar. (Kondo. I, 2014).

Kesimbangan asam basa didalam tubuh diatur oleh ginjal bekerja ekstra 
mengeluarkan sisa efek toksik dari obat yang dikomsumsi dalam jangka waktu yang cukup lama. Hal ini mengakibatkan ginjal harus bekerja ekstra terus-menerus yang memungkinkan terjadinya kelainan fungsi ginjal atau penurunan ekskresi pada ginjal, sehingga sisa metabolisme yang seharusnya dikeluarkan bersamaan melalui air seni akan menumpuk pada ginjal dan menyebabkan kelainan fungsi ginjal.

Gangguan fungsi ginjal akan menyebabkan penurunan laju filtrasi glomerulus (fungsi penyaringan ginjal) sehingga ureum, dan asam urat yang seharusnya disaring oleh ginjal untuk kemudian dibuang melalui air seni menurun, akibatnya memungkinan zat-zat tersebut akan meningkat di dalam darah.

Oleh karena itu, peneliti berkeinginan melakukan suatu penelitian tentang analisis hasil pemeriksaan ureum dan asam urat terhadap penderita tuberkulosis paru yang mengkonsumsi OAT pada fase intensif.

\section{METODE}

Jenis penelitian ini adalah observasi laboratorium yang bersifat deskriptif. Penelitian ini dilaksanakan di Laboratorium Kimia Klinik Jurusan Analis Kesehatan Poltekkes Kemenkes Makassar dan tempat pengambilan sampel penelitian di PKM Jumpandang Baru dan PKM Bara-Baraya Kota Makassar. Penelitian dilaksanakan pada tanggal 15 Februari s/d 9 Mei 2018.

Sampel dalam penelitian ini adalah penderita Tuberkulosis Paru yang mengonsumsi OAT pada fase intensif yang diambil secara Purposive samplin, dengan kriteria : a. Penderita Tuberkulosis paru.

b. Mengonsumsi OAT pada fase intensif (selama 2 bulan) .

c. Bersedia sebagai sampel penelitian

Instrument Penelitian Instrument yang digunakan adalah spoit 3 cc, tabung (non antikoagulan), tourniquet, mikropipet 100 ul, tips biru dan kuning, alumunium foil, kapas, plaster, tissue, kuvet/tabung sampel, Photometer 5010 V5+, Box sampel, sentrifusserta alat pelindung diri yang terdiri dari jas laboratorium, masker dan handscoon. Sedangkan bahan penelitian yang digunakan dalam penelitian ini adalah serum, alkohol $70 \%$, aquadest, reagen ureum dan Asam Urat.

Prosedur Kerja

1. Pengambilan darah vena

Karet pembendung dipasang pada lengan kira-kira $10 \mathrm{~cm}$ di atas lipatan siku, dipilih bagian vena median cubital atau cephalic, kemudian dilakukan palpasi untuk memastikan posisi vena; pasien diminta mengepalkan tangannya agar vena terlihat jelas, didesinfeksi dangan kapas alkohol $70 \%$, dibiarkan sampai kering. Kemudian, Ditusuk bagian vena, akan terlihat darah masuk ke dalam semprit. lalu karet pembendung dilepas, setelah volume darah dianggap cukup, diminta pasien membuka kepalan tangannya, diletakkan kapas ditempat tusukan lalu segera dilepaskan/ditarik jarum. Kemudian, ditekan kapas beberapa saat lalu diplester selama kira-kira 15 menit. Darah dispoit tadi disimpan kedalam tabung yang telah disediakan sesuai dengan identitas dan jenis pemeriksaan. Jarum bekas pakai 
dibuang pada tempat pembuangan khusus.

2. Prinsip Alat Photometer 5010 V5+

Pengukuran penyerapan sinar akibat interaksi sinar yang mempunyai panjang gelombang tertentu dengan larutan atau zat warna yang dilewatinya. Kebanyakan photometers mendeteksi cahaya dengan photoresistors, dioda atau photomultipliers. Untuk menganalisis cahaya, fotometer bisa mengukur cahaya setelah melalui filter atau melalui monokromator penentuan ditentukan panjang gelombang atau untuk analisis terhadap distribusi spektrum cahaya. Alat fotometer pada prinsipnya memiliki kesamaan seperti spektrofotometer, yang membedakan hanyalah penggunaan filter sebagai monokromatornya. Filter hanya digunakan untuk meneruskan cahaya namun dapat juga menyerap sumber radiasi dari gelombang lain. Penggunaan fotometer lebih sering digunakan untuk kebutuhan laboratorium klinis (analisa darah).

3. Prosedur kerja Photometer

a. Tahapan proses pengukuran Ureum metode Berthelot Urea dihidrolisis oleh adanya air dan urease menghasilkan amoniak dan karbondioksida Reaksi modifkasi berthelot ion amonium bereaksi hipoklorit dan salisilat untuk membentuk warna hijau. Peningkatan absorbansi pada $546 \mathrm{~nm}$ atau $578 \mathrm{~nm}$ sebanding dengan konsentrasi urea dalam sampel.
Persiapan Reagen : reagen dan standar siap digunakan

Persiapan Sampel : Serum/ plasma

Panjang Gelombang : $520 \mathrm{~nm}$, 570 - $600 \mathrm{~nm}, 546 \mathrm{~nm}$

Suhu : $20-25^{\circ} \mathrm{C}$ atau $37^{\circ} \mathrm{C}$

Pengukuran : Terhadap blanko reagen $(\mathrm{Rb})$ hanya dibutuhkan satu

Blankoperseri.

Disiapkan tabung 3 buah tabung untuk blanko, standar dan sampel pada tabung kedua dimasukkan $10 \mu \mathrm{l}$ standar dan tabung ketiga $10 \mu \mathrm{l}$ sampel. Kemudian tambahkan reagen pada ketiga tabung masingmasing $1000 \mu \mathrm{l}$, campur dan diinkubasi selama 10 menit $20-25^{\circ} \mathrm{C}$ atau 5 menit pada $37^{\circ} \mathrm{C}$. Ukur absorben sampel/standar terhadap reagen blanko setelah 15 menit.

Perhitungan

$\mathrm{C}: \mathrm{BUN}=\underline{\text { Abs Sampel }} \times 37,28 \mathrm{mg} / \mathrm{dl}$ Abs Standar

Nilai Normal

Serum $\quad=10-50 \mathrm{mg} / \mathrm{dl}$

b. Tahapan proses pengukuran asam urat metode Uricase - PAP

Persiapan Reagen : Reagen dan standar siap pakai

Persiapan Sampel : Serum/ plasma Panjang Gelombang: 520nm Hg $546 \mathrm{~nm}$

Suhu : $20-25{ }^{\circ} \mathrm{C}$ atau $37^{\circ} \mathrm{C}$

Pengukuran :Terhadap blanko reagen $(\mathrm{Rb})$ hanya dibutuhkan satu Blanko perseri

Cara Kerja

Disiapka 3 buah tabung untuk blanko, standar dan sampel pada tabung kedua dimasukkan $20 \mu \mathrm{l}$ standar dan tabung ketiga $20 \mu \mathrm{l}$ sampel. Kemudian tambahkan 
Jurnal Media Analis Kesehatan, Vol. 10, No.1, Juni 2019

http://journal.poltekkes-mks.ac.id/ojs2/index.php/mediaanalis

e-ISSN : 2621-9557

p-ISSN : 2087-1333

reagen pada ketiga tabung masing-masing $1000 \mu l$.

Dihomogenkan, Inkubasi 10 menit pada suhu $20-25^{\circ} \mathrm{C}$ atauselama 5menit pada suhu $37^{\circ} \mathrm{C}$.Ukurabsorben

sampel/standar terhadapreagen blanko dalam 15 menit.

Perhitungan

Serum/Plasma :

$\mathrm{C}=\underline{8 \times \text { Abs Sampel }(\mathrm{mg} / \mathrm{dl})}$ Abs standar

Nilai Normal

Laki - laki : $3.4-7.0 \mathrm{mg} / \mathrm{dl}$

Perempuan : $2.4-5.7 \mathrm{mg} / \mathrm{dl}$

Analisa Data

Analisa data disajikan dalam bentuk tabel dan dianalisa secara deskriptif dengan melihat hasil analisa pemeriksaan kadar ureum dan asam urat penderita TBC Paru pada fase intensif, berdasarkan persentase

$$
\mathrm{P}(\%)=\mathrm{t} / \mathrm{n} \times 100 \%
$$

Keterangan

$\mathrm{P}$ : Persentase

$\mathrm{T}$ : Jumlah sampel yang diperiksa dengan kadar mengalami Peningkatan diatas nilai normal.

$\mathrm{n}$ : Jumlah frekuensi/sampel yang diperiksa.

\section{HASIL}

Berdasarkan hasil penelitian yang telah dilaksanakan pada tanggal 15 Februari s/d 9 Mei 2018 di Laboratorium Kimia Klinik Jurusan Analis Kesehatan Poltekkes Kemenkes Makassar, dari 30 sampel penderita $\mathrm{Tb}$ Paru yang mengonsumsi Obat Anti Tuberkulosis (OAT) fase intensif diperoleh hasil seperti pada tabel berikut :

dengan rumus :

Tabel 1. Hasil pemeriksaan ureum pada penderita $\mathrm{Tb}$ Paru yang mengonsumsi OAT fase intensif.

\begin{tabular}{cccccc}
\hline No & $\begin{array}{c}\text { Kode } \\
\text { Pasien }\end{array}$ & $\begin{array}{c}\text { Jenis } \\
\text { Kelamin }\end{array}$ & $\begin{array}{c}\text { Umur } \\
\text { (Tahun) }\end{array}$ & $\begin{array}{c}\text { Ureum } \\
\text { (mg/dl) }\end{array}$ & Keterangan \\
\hline 1 & X-1 & L & 48 & 52 & Normal \\
2 & X-2 & L & 24 & 78 & Meningkat \\
3 & X-3 & L & 47 & 52 & Normal \\
4 & X-4 & P & 61 & 82 & Meningkat \\
5 & X-5 & L & 23 & 36 & Normal \\
6 & X-6 & L & 41 & 24 & Normal \\
7 & X-7 & P & 74 & 79 & Meningkat \\
8 & X-8 & L & 20 & 23 & Normal \\
9 & X-9 & L & 25 & 29 & Normal \\
10 & X-10 & P & 36 & 49 & Normal \\
11 & X-11 & L & 31 & 30 & Normal \\
12 & X-12 & P & 47 & 29 & Normal \\
13 & X-13 & P & 30 & 21 & Normal \\
14 & X-14 & L & 32 & 25 & Normal \\
15 & X-15 & L & 47 & 60 & Meningkat \\
16 & X-16 & L & 43 & 33 & Normal \\
17 & X-17 & L & 52 & 37 & Normal \\
18 & X-18 & L & 23 & 21 & Normal \\
19 & X-19 & P & 59 & 33 & Normal
\end{tabular}




\begin{tabular}{|c|c|c|c|c|c|}
\hline 20 & $X-20$ & $\mathrm{P}$ & 53 & 14 & Normal \\
\hline 21 & $X-21$ & $\mathrm{~L}$ & 62 & 76 & Meningka \\
\hline 22 & $X-22$ & $\mathrm{P}$ & 50 & 33 & Normal \\
\hline 23 & $X-23$ & $\mathrm{P}$ & 70 & 35 & Normal \\
\hline 24 & $X-24$ & $\mathrm{~L}$ & 30 & 22 & Normal \\
\hline 25 & $X-25$ & $\mathrm{~L}$ & 24 & 21 & Normal \\
\hline 26 & $X-26$ & $\mathrm{~L}$ & 31 & 42 & Normal \\
\hline 27 & $X-27$ & $\mathrm{P}$ & 27 & 50 & Normal \\
\hline 28 & $X-28$ & $\mathrm{~L}$ & 48 & 41 & Normal \\
\hline 29 & $X-29$ & $\mathrm{P}$ & 52 & 54 & Normal \\
\hline 30 & $X-30$ & $\mathrm{~L}$ & 47 & 14 & Normal \\
\hline
\end{tabular}

Pada tabel 1 menunjukkan hasil pemerinksaan ureum dari 30 sampel penderita $\mathrm{Tb}$ Paru yang mengkonsumsi OAT fase intensif terdapat 25 sampel masih dalam batas normal dengan persentase sebanyak
83,33\% dan 5 sampel menunjukkan hasil pemeriksaan ureum yang meningkat dengan persentase 16,67 $\%$.

Tabel 2: Hasil pemeriksaan Asam urat penderita Tb Paru yang mengonsumsi OATfase intensif

\begin{tabular}{cccccc}
\hline No & Kode Pasien & $\begin{array}{c}\text { Jenis } \\
\text { Kelamin }\end{array}$ & $\begin{array}{c}\text { Umur } \\
\text { (Tahun) }\end{array}$ & $\begin{array}{c}\text { Asam Urat } \\
\text { (mg/dl) }\end{array}$ & Keterangan \\
\hline 1 & X-1 & L & 48 & 7 & Normal \\
2 & X-2 & L & 24 & 10 & Meningkat \\
3 & X-3 & L & 47 & 13 & Meningkat \\
4 & X-4 & P & 61 & 8 & Meningkat \\
5 & X-5 & L & 23 & 14 & Meningkat \\
6 & X-6 & L & 41 & 10 & Meningkat \\
7 & X-7 & P & 74 & 12 & Meningkat \\
8 & X-8 & L & 20 & 6 & Normal \\
9 & X-9 & L & 25 & 7 & Normal \\
10 & X-10 & P & 36 & 5 & Normal \\
11 & X-11 & L & 31 & 10 & Meningkat \\
12 & X-12 & P & 47 & 11 & Meningkat \\
13 & X-13 & P & 30 & 6 & Normal \\
14 & X-14 & L & 32 & 7 & Normal \\
15 & X-15 & L & 47 & 9 & Meningkat \\
16 & X-16 & L & 43 & 3 & Normal \\
17 & X-17 & L & 52 & 10 & Meningkat \\
18 & X-18 & L & 23 & 6 & Normal \\
19 & X-19 & P & 59 & 6 & Normal \\
20 & X-20 & P & 53 & 7 & Meningkat \\
21 & X-21 & L & 62 & 6 & Normal \\
22 & X-22 & P & 50 & 18 & Meningkat \\
23 & X-23 & P & 70 & 7 & Meningkat \\
\hline
\end{tabular}




\begin{tabular}{llllcl}
\hline 24 & X-24 & L & 30 & 8 & Meningkat \\
25 & X-25 & L & 24 & 10 & Meningkat \\
26 & X-26 & L & 31 & 8 & Meningkat \\
27 & X-27 & P & 27 & 7 & Meningkat \\
28 & X-28 & L & 48 & 7 & Normal \\
29 & X-29 & P & 52 & 5 & Normal \\
30 & X-30 & L & 47 & 9 & Meningkat \\
\hline
\end{tabular}

Sumber: Data Primer 2018

Pada tabel 2 menunjukkan hasil pemeriksaan asam urat dari 30 sampel penderita $\mathrm{Tb}$ Paru yang mengonsumsi OAT fase intensif terdapat 12 sampel masih dalam batas normal dengan presentase sebanyak $40,0 \%$ dan 18 sampel menunjukkan hasil pemeriksaan ureum yang meningkat sampel dengan presentase $60,0 \%$.

\section{PEMBAHASAN}

Pada hasil penelitian yang telah dilakukan diperoleh hasil pemeriksaan ureum pada penderita $\mathrm{Tb}$ Paru $5 \quad(16,67 \%)$ sampel mengalami peningkatan kadar ureum dengan kadar rata-rata $39,83 \mathrm{mg} / \mathrm{dl}$, dan $25 \quad(83.33 \%) \quad$ sampel menunjukkan kadar ureum normal dengan kadar ureum $<50 \mathrm{mg} / \mathrm{dl}$. kondisi Peningkatan kadar ureum dalam darah dapat disebabkan oleh adanya gangguan ekskresi urea yang tertahan didalam darah.

$$
\text { Urea meningkat dapat }
$$
diakibatkan dari Pengobatan Obat Anti Tuberkulosis. Konsumsi OAT Kombinasi Dosis Tetap yang terdiri dari isoniazid $(\mathrm{H})$, Rifampisin (R), Pirazinamid (Z), dan Etambutol (E) diberikan setiap hari secara rutin selama 2 bulan (2HRZE) pada fase intensif. Oleh karena itu, perlu adanya bentuk pengawasan langsung oleh pengawas minum obat (PMO) untuk menjamin kepatuhan pasien menelan obat, biasanya pasien menular menjadi tidak menular dalam kurun waktu 2 minggu. Sebagian besar pasien Tb Paru BTA positif menjadi BTA negatif (konversi) dalam 2 bulan. Lamanya pengobatan OAT memberikan efek samping begitu menyiksa bagi penderita, diantaranya efek minor yaitu gatal-gatal, kemerahan di kulit, urin kemerahan, rasa panas di kaki, nyeri sendi sampai efek mayor yaitu gagal ginjal.

Beberapa jenis OAT yang bisa menjadi indikasi pemicu gangguan fungsi ginjal ialah obat Rifampisin (R) merupakan antibiotika oral yang mempunyai aktivitas bakterisida terhadap Mycobacterium tuberculosis. Mekanisme kerja rifampisin dengan jalan menghambat kerja enzim DNA-dependent RNA polymerase yang mengakibatkan sintesa RNA mikroorganisme dihambat. Dan sebagai komponen kunci dalam setiap regimen pengobatan. Rifampisin selalu diikutkan kecuali bila ada kontraindikasi, rifampisin yang merupakan salah satu antibiotik penyebab nefritis interstisial yaitu peradangan pada sel-sel ginjal. Nefritis adalah peradangan pada ginjal yang terjadi karena infeksi bakteri penyakit pada nefron. Bakteri ini masuk melalui saluran pernafasan kemudian dibawah oleh darah ke ginjal. Karena infeksi ini nefron mengalami peradangan sehingga protein dan sel-sel darah yang masuk bersama urine primer tidak dapat 
disaring dan keluar bersama urine. Selain itu, nefritis dapat menyebabkan uremia.

Berkurangnya kemampuan fungsi ekskresi pada ginjal ini yang menyebabkan senyawa-senyawa obat yang tidak termetabolisme akan dikeluarkan melalui ginjal dimana proses ekskresi obat dalam tubuh melibatkan tiga proses yaitu Filtrasi glomerulus, Sekresi aktif di tubulus proksimal, Reabsorbsi pasif di sepanjang tubulus. Ketika di filtrasi glomelurus terjadi disfungsi pada ginjal dalam menghasilkan ultrafiltrat yaitu plasma minus protein, semua obat bebas akan keluar dalam ultrafiltrasi sedangkan yang terikat protein tetap tinggal dalam darah.

Berdasarkan hasil penelitian yang telah dilakukan pada penderita Tb Paru, hasil pemeriksaan ureum yang meningkat menegaskan bahwa ureum sebagai uji skrinning pemeriksaan fungsi ekskresi ginjal menggambarkan belum terdapat pengaruh OAT terhadap fungsi ekskresi ginjal, karena pemberian OAT tetap mempertimbangkan kesesuaian indikasi yaitu penggunaan obat sesuai dengan kebutuhan klinis yang dilihat dari diagnosis, kesesuaian jenis OAT berdasarkan berat badan pasien pada aspek kesesuaian dosis penggunaan OAT, kepatuhan selama pengobatan OAT, dan riwayat peyakit selain Tb Paru untuk mencegah terjadinya kontraindikasi karena dikhwatirkan disatu sisi obat bertujuan mematikan bakteri namun, disisi lain memberikan dampak kepada organ selain ginjal yaitu hepar. Seperti, Hepatitis akibat imbas obat atau drug induced hepatitis (DIC) akibat penggunaan obat-obat hepatotoksik dan beberapa faktor lain yang menyebabkan kontraindikasi ialah adanya riwayat gagal ginjal, dan koinfeksi HIV-TB.

Terdapat beberapa faktor yang memicu peningkatan ureum diantaranya ialah terlalu banyak mengonsumsi makanan yang mengandung tinggi protein dan usia. Faktor pertama ialah mengonsumsi makanan tinggi protein, asupan makanan yang tinggi protein akan menyebabkan tingginya kadar ureum dan kreatinin. Kondisi susah buang air kecil pada penderita, sehingga ureum yang seharusnya dikeluarkan melalui urin menjadi menumpuk dalam darah. Tingginya kadar ureum dalam darah yang tidak bisa dikeluarkan karena fungsi ginjal yang menurun dapat menjadi toksik didalam tubuh. karena, ureum sendiri merupakan suatu zat sisa metabolisme protein melalui pertukaran protein yaitu penguraian dan resisten semua protein sel yang berlangsung terus menerus. Untuk memantau fungsi ekskresi ginjal ureum digunakan sebagai salah satu pemeriksaan laboratorium untuk uji skrining fungsi ginjal merupakan salah satu produk dari pemecahan protein dalam tubuh.

Penelitian lain yang
mendukung ialah oleh Nura Ma'shumah (2013) tentang hubungan asupan protein dengan kadar ureum, kreatinin, dan kadar hemoglobin darah pada penderita gagal ginjal kronik menyatakan bahwa asupan protein / nutrisi memiliki hubungan terhadap pengaruh kadar ureum.

Faktor kedua ialah usia, semakin tua usia erat kaitanya terhadap penurunan fungsi organ, hal ini karena perubahan anatomi tubuh, dan fungsional dalam ginjal. Dengan meningkatnya usia, jumlah nefron 
pada ginjal menurun dan menyebabkan fungsi ginjal menjadi menurun.

Jika mengkonsumsi OAT dengan waktu yang lama, tidak teratur dan tidak mengikuti petunjuk Dokter, maka akan berpengaruh terhadap organ ginjal. Hal ini disebabkan karena fungsi ginjal adalah sebagai alat ekskresi tubuh, Dan apabila terjadinya kerusakan fungsi ginjal, maka ginjal tidak mampu berkerja dengan baik dan mengakibatkan kadar ureum meningkat. Peningkatan kadar ureum terjadi karena ginjal rentan terhadap efek toksik. Peningkatan yang terjadi dalam batas normal ini dapat disebabkan karena Rifampisin yang merupakan salah satu antibiotik penyebab nefritis interstisial yaitu peradangan pada selsel ginjal yang bukan bagian dari unit pengumpulan cairan. dimana nefritis interstisial akut akibat obat merupakan reaksi hipersensitivitas yang terbalik terhadap sejumlah obatobatan yang meningkat. Reaksi mulai timbul kurang lebih 15 hari setelah pemaparan dengan obat. Gangguan fungsi ginjal sedang sampai berat dapat terjadi, tetapi dapat menghilang segera atau perlahan-lahan dengan dihentikannya obat, sehingga meskipun secara statistik memang terjadi perbedaan bermakna, namun secara substansi tidaklah mempunyai perbedaan yang berarti, karena semua hasil ureum dalam batas normal, sehingga disimpulkan tidak ada peningkatan kadar ureum antara sebelum dan setelah pengobatan OAT- KDT selama enam bulan dibandingkan dengan nilai normal.

Hal ini berbeda dengan hasil penelitian asam urat mengalami peningkatan kadar pada $18(60,0 \%)$ sampel penderita $\mathrm{Tb}$ Paru yang mengonsumsi OAT fase intensif. Peningkatan kadar asam urat dalam darah (hiperurisemia) disebabkan oleh peningkatan produksi (overproduction), dan penurunan pengeluaran (underexcretion) asam urat melalui ginjal.

Peningkatan kadar asam urat dalam darah erat kaitanya dengan kondisi ginjal penderita $\mathrm{Tb}$ paru. Terjadinya peningkatan asam urat akibat penumpukan purin pada area sendi. Tingginya kadar asam urat yang di picu penumpukan purin dalam darah akan membuat terbentuknya kristal yang menumpuk pada persendian.

Purin ini sebenarnya tidak akan menjadi masalah selama kadarnya masih ada dalam batas normal tubuh namun akan menyebabkan resiko jika meningkat didalam darah, penyebabnya ialah dengan adanya kombinasi ZE pada pengobatan Tb Paru digunakan OAT4 KDT terdiri dari Isoniazid $(\mathrm{H})$, Rifampisin (R), Pirazinamid (Z) dan Etambutol (E) pada fase intensif.

Pirazinamid dan Ethambutol merupakan kombinasi ZE yang bersifat tuberkulostatik. Dimana obat pirazinamid memiliki metabolit (asam pirazinoat), dan Ethambutol memiliki $10 \%$ sisa metabolisme diantaranya asam karboksilat dan dapat menyebabkan hiperurisemia. Jumlah asam dalam tubuh menjadi meningkat jika mengkonsumsi suatu asam atau suatu bahan yang diubah menjadi asam, dan dapat mengurangi ekskresi asam urat melalui ginjal.

Berdasarkan kerja obat Pirazinamid dan Etambutol memfasilitasi pertukaran ion di tubulus ginjal menyebabkan reabsorpsi berlebihan asam urat sehingga terjadi adanya gangguan 
pada metabolisme tubuh yang biasanya normal menjadi sangat terganggu. Inilah yang akan membuat kadar asam urat menjadi terus mengalami penumpukan dan akan sangat sulit dikurangi. Jika sudah seperti itu tanda-tanda asam urat seperti nyeri pada sendi, peradangan hingga bengkak pada area sendipun akan segera muncul dan menimbulkan hiperurisemia.

Metabolisme purin yang masuk dalam tubuh akan dibantu dan di ekskresi oleh ginjal untuk dikeluarkan melalui saluran urin, jika kadarnya berlebihan namun ginjal masih bisa mengatasinya maka tidak akan menjadi masalah untuk ginjal. Namun jika kadarnya sudah benarbenar sangat berlebihan maka ginjal juga sudah tidak bisa mengekresi kelebihan purin dengan baik, akibatnya malah akan menyebabkan masalah pada fungsi ginjal. Bahkan bisa saja penderita mendapati ada batu ginjal dalam kandung kemih nya. Oleh sebab itu, adanya asam urat memang sangat berpengaruh buruk selain pada sendi juga pada organ yang ada dalam tubuh.

Munculnya efek samping dari OAT dapat disebabkan oleh salah satu atau lebih jenis obat yang dikandungnya. Adapun jenis obat yang terkandung dalam FDC antara lain; Rifampisin (R), isoniazid $(\mathrm{H})$, pirazinamid (Z), Etambutol (E), dan streptomisin (S). Besarnya efek nyeri sendi disebabkan oleh Pirazinamid (Z). Jenis obat lini pertama yang paling sering menimbulkan efek samping adalah kombinasi ZE.

Peningkatan bermakna kadar asam urat serum pada pengobatan dengan OAT terutama terlihat selama 2 bulan pada fase intensif. Pemberian OAT 4 KDT, terdapat peningkatan bermakna kadar asam urat serum pada fase intensif, terutama pada minggu ke-4 dan relatif menetap pada minggu ke-8 pengobatan OAT - KDT. Pirazinamid dan Etambutol memfasilitasi pertukaran ion di tubulus ginjal menyebabkan reabsorpsi berlebihan asam urat sehingga menimbulkan hiperurisemia.

Umur sama sekali tidak berpengaruh terhadap kadar asam urat. Diketahui enzim urikinase yang mengoksidasi asam urat menjadi alotonin yang mudah dibuang akan menurun seiring dengan bertambah tuanya umur seseorang. Jika pembentukan enzim ini terganggu maka kadar asam urat darah menjadi naik. Hal ini membuktikan bahwa tidak selalu orang yang berusia lebih tua cenderung memiliki kadar asam urat yang lebih tinggi. Meskipun diketahui pada usia > 40 tahun terjadi penurunan fungsi ginjal. Namun pada kasus $\mathrm{Tb}$ paru penderita dengan usia muda juga dapat mengalami hiperurisemia.

Terjadinya gangguan asam urat dipicu oleh beberapa hal. Beberapa faktor risiko yang membuat seseorang terserang asam urat yaitu, makanan yang mengandung purin berlebih, komsumsi alkohol, berat badan berlebih, dehidrasi atau kurang minum, dan genetik.

Dari kedua hasil pemeriksaan fungsi ekskresi ginjal pada penderita $\mathrm{Tb}$ paru yang mengonsumsi OAT pada fase intensif, dapat disimpulkan bahwa tingkat asam urat dapat meningkat lebih awal dari pada tingkat ureum dalam darah, Peningkatan kadar asam urat dalam serum (hiperuresemia) bergantung kepada fungsi ginjal, dan kecepatan metabolisme purin. Kondisi pada 
kegagalan glomerulus ginjal atau bila ada obstruksi aliran keluar urin, asam urat serta ureum dan kreatinin terakumulasi. Asam urat tinggi yang dapat terjadi tanpa azotemia atau uremia disebabkan oleh lesi ginjal atau perubahan metabolisme asam urat.

Dari hasil penelitian telah didapatkan gambaran kadar asam urat yang meningkat sebanyak $60,0 \%$. Kondisi meningkatnya kadar asam urat ini dipicu penumpukan purin dalam darah akibat purin yang tidak termetabolisme dengan baik oleh enzim Hypoxanthine -Guanine Phosphoribosyl Transferase (HGPRT) yang berperan dalam mengubah purin menjadi nukleutida purin agar dapat dugunakan kembali sebagai penyusun DNA dan RNA (Adenosine dan Guanosin). Jika enzim ini mengalami defisiensi penumpukan purin dalam darah akibat efek toxic komsumsi OAT yang mengandung banyak asam, maka peran enzim berkurang dan purin menjadi meningkat. Purin yang tidak termetabolisme oleh enzim HGPRT maka oleh enzim xanthine oxidase akan dimetabolisme sehingga pada akhirnya kandungan asam urat meningkat dalam darah pada kondisi hiperusemia.

Beberapa hal yang tidak diteliti dalam penelitian ini adalah faktor lain penyebab peningkatan asam urat seperti berat badan, kebiasaan penderita $\mathrm{Tb}$ Paru terhadap komsumsi makanan dan minuman yang mengandung tinggi purin yang bisa menjadi pemicu meningkatnya asam urat selain pengobatan OAT. Hasil penelitian ini telah menggambarkan bahwa ada kaitan antara asam urat terhadap ginjal penderita $\mathrm{Tb}$ Paru yang mengonsumsi
OAT pada fase intensif namun belum dapat di kategorikan sebagai dampak awal penurunan fungsi eksresi pada ginjal sehingga meningkat dalam darah. Gejala asam urat ini lebih dahulu didapatkan penderita TBC Paru karena salah satu pemicu ialah akibat OAT kombinasi ZE, namun untuk gejala yang ditimbulkan pada ginjal akibat adanya penumpukan asam urat tidak akan hadir pada tahap awal fase intensif, karena dampak gejala baru bisa dirasakan untuk tahap lanjutan. Pada tahap lanjutan tersebutlah jika peningkatan asam urat berkepanjangan maka batu ginjal akan terbentuk dan apabila berlanjut maka infeksi berulang terjadi pada ginjal dan akhirnya bisa menyebabkan ketingkat lebih serius yaitu gangguan fungsi ekskresi ginjal sampai pada gagal ginjal kronis. Hal ini berbeda pada hasil pemeriksaan ureum, 25 sampel menunjukkan kadar ureum normal (83.33\%) dengan kadar ureum < $50 \mathrm{mg} / \mathrm{dl}$. Hal ini menggambarkan bahwa kemampuan ginjal yang masih baik dalam mengekskresi zat -zat sisa metabolisme dalam tubuh. Sehingga pengobatan OAT KDT masih aman digunakan selama sesuai dengan dosis dan petunjuk dari Dokter.

\section{KESIMPULAN}

Dari hasil penelitian 30 sampel penderita tuberkulosis Paru yang mengomsumsi Obat Tuberkulosis diperoleh hasil pemeriksaan kadar ureum yang meningkat sebanyak 5 $(16,67 \%)$ sampel dan yang menunjukkan kadar ureum normal sebanyak $25(83.33 \%)$ sampel, dan hasil pemeriksaan asam urat yang mengalami peningkatan sebanyak 18 $(60,0 \%)$ sampel dan yang 
menunjukkan kadar ureum normal 12 $(40,0 \%)$.

\section{SARAN}

Bagi penderita $\mathrm{Tb}$ Paru sebaiknya mengkonsumsi OAT secara teratur dan mengikuti petunjuk dari Dokter serta dapat melakukan pemeriksaan laboratorium untuk jenis parameter pemeriksaan yang lain.

\section{DAFTAR PUSTAKA}

Arikunto S, 2010, Prosedur Penelitian Suatu Pendekatan Praktik. Rineka Cipta. Jakarta.

Anonim, 2017, Buku Panduan Pemeriksaan Sputum Bta, Http://Med.Unhas. Ac.Id/ Kedokteran/WpContent/Uploads /2017/09/Sputum-2017.Pdf

Anonim, 2017, Hubungan Asam Dengan Ginjal dan Cara Mengatasinya Asam urat.com. htm_Diakses 27 Juni 2017

Alchudri, A, 2018. Ekskresi Obat (Ekskresi obat - Anak-farmasi. com.htm) Diakses pada 15 juni 2017

Berawi, K.N. 2009, Fisiologi Ginjal dan Cairan Tubuh. Edisi 2. Penerbit Universitas lampung, Bandar Lampung.

Carolus, 2017. Tuberculosis Bisa Disembuhkan Edisi 1. Penerbit PT Gramedia, Jakarta.

Carrol N, 2002, Purine and Pyrimidine Metabolism ; Purine Catabolism, https://library.med. utah.edu/NetBiochem/pupyr/pp.h $\underline{\mathrm{tm}}$

DepKes RI, 2003, Pasien Pendarahan Ureum Meningkat. Depkes RI, Jakarta.

Elfindri; HasnitaE; Abidin Z; Mahmud R; Elmiyasna; Azis E, 2011, Metodologi Penelitian
Frances, K, 1995, Tinjauan Klinis Hasil PemeriksaanLaboratorium, EGC., Jakarta

Ganong, W. F. 2009, Buku Ajar Fisiologi Kedokteran. Edisi 22. EGC, Jakarta.

Goodman \& Gilman. 2010. Manual Farmakologi dan Terapi. EGC, Jakarta

Jawetz, Melnick, \& Adelberg. 2014. Mikrobiologi Kedokteran, Buku Kedokteran EGC, Jakarta.

Irianto A, 2004, Statistik Konsep Dasar \& Aplikasinya. Kencana Prenada Media. Jakarta.

Kemenkes RI, 2011, Pedoman Nasional Penanggulangan TBC, Dirjen Pengendalian Penyakit dan Penyehatan Lingkungan, Jakarta

Kemenkes RI, 2016, Tuberculosis Temukan Obati Sampai Sembuh. (Http://Www.Depkes.Go.Id/Arti cle/View/16040400008/Tos-TbTemukan-Tb-Obati-SampaiSembuh.Html)

Kemenkes RI, 2016, Info Dating Tuberculosis (www.depkes.go. $\underline{\mathrm{id} / \text { download.php?file }=\text { download }}$ /pusdatin/infodatin)

Kondo.I, 2014. Gambaran Kadar Asam Urat Pada Penderita Tuberkulosis Paru Yang Menerima Terapi Obat Anti Tuberkulosis Di Rsup Prof. Dr. R.D. Kandou Manado Periode Juli 2014 - Juni 2015 (https:/ lejournal.unsrat.ac.id/index.php/ eclinic/article/download/10980/ 1069). Diakses 16 Desember 2017.

Magnus M, 2011, Buku Ajar Epidemiologi Penyakit Menular. EGC., Jakarta

Maryani L; Muliani R; 2010, Epidemiologi 
Jurnal Media Analis Kesehatan, Vol. 10, No.1, Juni 2019

http://journal.poltekkes-mks.ac.id/ojs2/index.php/mediaanalis

Pendekatan Penelitian, Penerbit Graha Ilmu, Yogyakarta.

Masriadi, 2017. Epidemiologi Penyakit Menular. Edisi 2. Penerbit PT. Raja Grafindo Persada, Depok Jakarta.

Moore KL., Agur AMR. 2002. Anatomi Klinis Dasar. Penerbit Hipokrates. Jakarta.

Naga, Sholeh.S. 2013, Buku Panduan Lengkap Ilmu Penyakit Dalam, Divapress, Yogyakarta.

Nanda, NT, 2015, Analisa Kadar Ureum Dalam Serum Penderita Tb Paru Yang Mengkonsumsi Obat Anti Tuberkulosis Lebih dari 4 bulan di UPT Kkesehatan Paru Masyarakat Medan (file:///C:/Users/User/Downloads /12034119 001(1).pdf) Diakses 28 November 2017.

Nizar M, 2017, Pemberantasan dan Penanggulangan Tuberculosis, Edisi 1, Gosyen Publishng, Yogyakarta.
Noor N.N, 2006, Pengantar Epidemiologi Penyakit Menular, Jakarta : Rineka Cipta.

Nura Ma'shumah, 2013, Hubungan Asupan protein Dengan Kadar Ureum, Kreatinin dan Kadar Hb, Skripsi, Semarang

Purwoko T, 2009, Fisiologi Mikroba. Penerbit Bumi Aksara, Jakarta.

Robiyanto, Dkk, 2014, Evaluasi Penggunaan Obat Anti Tuberkulosis Paru Pada Pasien Dewasa Rawat Jalan Di Unit Pengobatan Penyakit Paru-Paru (Up4) Pontianak.

Upoyo, S, Dkk, 2009, Analisis Faktor-Faktor Yang Mempengaruhi Kadar Asam Urat Padapekerja Kantor Di Desa Karang Turi, Kecamatan Bumiayu, Kabupaten Brebes

WHO Global Tuberculosis Report, 2017. 